\title{
CMA urges prescription-only antibiotics for agricultural use
}

A ntibiotics shouldn't be used in Canada's agricultural sector except by prescription from veterinarians, the nation's doctors say.

Arguing that antibiotic misuse in the agricultural sector is rampant, delegates to the Canadian Medical Association's 144th annual general meeting in St. John's, Newfoundland and Labrador, adopted a resolution Aug. 24 urging the implementation of mandatory veterinary prescriptions for all antibiotics used in animals.

The motion was among a raft of sharp rebukes issued by delegates at the gathering. Others include a condemnation of the Conservative government for continuing to block the inclusion of chrysotile asbestos in the Rotterdam Convention, as well as a stern warning to the public to find safer ways to use cell phones so as to minimize the potentially harmful effect that radio frequencies may have on the brain.

The motion to press for introduction of mandatory antibiotic prescriptions in agriculture flies in the face of the federal government's unwillingness to develop a concerted national response to antibiotic misuse in agriculture or to contain antibiotic resistance within medicine. Critics have repeatedly charged that Ottawa's inaction is deliberate, particularly its failure to establish a Canadian Centre for Antimicrobial Resistance after dissolving a national committee (www.cmaj.ca /lookup/doi/10.1503/cmaj.109-3109)

Ottawa has also failed to tighten offlabel drug usage on farms (www.cmaj .ca/lookup/doi/10.1503/cmaj.091009).

Nor did it act to close a legal loophole allowing massive imports of unapproved drugs for agricultural use (www.cmaj.ca /lookup/doi/10.1503/cmaj.090525).

Delegates argued the government's inertia on the file must end.

\author{
"Because agriculture accounts for \\ the highest volume of antibiotic use, the \\ farm environment serves as a reservoir \\ of resistant genes," British Columbia \\ delegate Dr. Bill Mackie told council. \\ "Low concentrations of antibiotics
}

that resistance found VRE in meat and manure on farms where the antimicrobials were used as growth promoters, he explained. Humans exposed to livestock that are colonized with the super bug methicillin-resistant Staphylococcus aureus have also been found to have a 138-fold higher risk of becoming colonized with those bacteria, Mackie said.

Countries such as Denmark that have restricted the use of antimicrobials in agriculture have substantially reduced both antimicrobial consumption and resistance with little economic impact on industry, he argued. Between 1992 and 2008, for example, Danish farmers increased swine production by $47 \%$ while halving their use of antibiotics.

Some delegates countered that mandatory prescriptions would indiscriminately raise barriers for Canadian hobby farmers, who are already strictly regulated and make only marginal contributions to the spread of antibiotic

used in animal feed have been found to induce random mutagenesis," while the dispersal of antibiotics into soil and water have been shown to enhance the risk of breaking natural barriers between bacterial groups via "horizontal transfer of genes" conferring resistance to bacteria that may not have even come in direct contact with the antibiotics, he explained.

This has serious health implications for patients, some of whom are dying as a consequence of resistant infections, particularly as the most common antimicrobials used in agriculture are either identical or related to those administered to humans, Mackie said.

During the early 1990s, vancomycinresistant Enterococcus (VRE) was detected among patients in Europe and a search for a community reservoir of resistance. Others questioned whether veterinary prescriptions would be an effective measure of control.

"I believe farming and agricultural processes need to be addressed but I'm not sure this council has a firm knowledge of what those processes are in order to decide on the one and only mechanism by which we have to do that," Alberta delegate Dr. Carolyn Lane explains in an interview. "Veterinarians may just be coerced by their clients to write prescriptions, so I think they and physicians should work together to decide on a way in general that they could address intensive farming practices that have created the need for widespread antibiotic use in agriculture."

Delegates also adopted a motion to educate Canadians on the dangers and 
ways of mitigating brain exposure to potentially harmful radio frequencies from cellphone use.

"We all need [cellphones] and we all like them, but this is a public health issue," said mover of the motion, Dr. Frank Sommers, citing the World Health Organization's recent classification of radio frequency electromagnetic fields as possible carcinogens.

While some delegates questioned how many children now talk on cellphones, rather than texting, Sommers argued that issuing a warning to the public is a "habituation issue."

"Cellphone companies even include in their instructions that the use of these phones should not be adjacent to our heads and ears. There should be a gap and most of us are not aware of that," he explained. "We have to get people used to not using the cellphone by putting it beside our ears, because every millimetre counts."

This lack of awareness of the potential dangers of cellphones is particularly concerning as parents provide phones to their children at younger ages as a form of "safety net," seconder of the motion Dr. Karen Dockrill added. "That includes children of the age of four and five going off to kindergarten. One parent even told me there's a product on the market now that includes a cellphone adaptation for babies so you can talk to them at night."

Other motions included the condemnation of asbestos exports. "We must send a strong message that their [the federal government's] unethical and shameful behaviour will not be tolerated by the doctors of Canada," British Columbia delegate Dr. Barry Turchen said.

Delegates also directed CMA to advocate for each province and territory to implement a patient charter within a national framework; to support the creation of a national body that will foster a pan-Canadian approach to quality improvement in health care; and to support the development and mandatory reporting of perioperative efficiency and quality performance indicators. Lauren Vogel, CMAJ

CMAJ 2011. DOI:10.1503/cmaj.109-3989 